\title{
JM
}

Volume 6 No. 2 (Oktober 2018)

(C) The Author(s)

\section{STUDI PENDAHULUAN : PENGUKURAN pH CAIRAN KETUBAN}

\author{
PILOT STUDY : pH MEASUREMENT OF AMNIOTIC FLUID
}

\author{
IKA PRATIWI ${ }^{1}$, SRI RAHAYU ${ }^{2}$ \\ JURUSAN MAGISTER TERAPAN KEBIDANAN, POLTEKKES \\ KEMENKES SEMARANG \\ JL. TIRTO AGUNG ; PEDALANGAN ; BANYUMANIK ; SEMARANG \\ E-mail : pratiwi.hastarto@gmail.com
}

\begin{abstract}
ABSTRAK
Intisari : Menurunkan angka kematian bayi dimulai sejak antenatal care dan berlanjut pada penanganan intranatal yang baik. Penegakan diagnosa yang akurat terjadinya ketuban pecah dini dapat mencegah komplikasi lebih lanjut pada ibu dan janin. Nilai basa pada cairan ketuban merupakan kunci dalam menegakkan diagnosa ketuban pecah dini, penggunakan lakmus test adalah pengukuran kadar basa yang umum digunakan, pada pengukuran dengan metode ini perubahan warna lakmus tidak jelas pada air ketuban responden nomer 3 dan nomer 5 . Pengukuran banding yang dilakukan pada 5 responden menggunakan $\mathrm{pH}$ meter merk nutron seri $\mathrm{PH}-009-\mathrm{A}$ dengan mengukur cairan ketuban responden yang sama, didapat hasil berturut turut sebagai berikut nilai $\mathrm{pH} 8.1$ pada responden pertama, $\mathrm{pH} 8.3$ pada responden nomer dua, pH 7.4 pada responden nomer tiga, $\mathrm{pH} 8.7$ pada responden nomor empat, dan $\mathrm{pH} 8.0$ pada responden nomor lima. lakmus test menunjukan perubahan warna samar pada nilai $\mathrm{pH} 7.4$ dan nilai $\mathrm{pH}$ 8.0. Kesimpulan teoritik melalui litelatur review menjelaskan bahwa pengukuran $\mathrm{pH}$ yang akurat dapat memberikan interprestasi data sebagai berikut : Usia Kehamilan, kadar surfactant yang menunjukan tingkat kematangan janin, usia kehamilan, komplikasi intrauterine seperti fetal distress dan infeksi intrauterine
\end{abstract}

Kata Kunci : pengkuran pH, cairan amnion, pH meter, lakmus test

\begin{abstract}
Abstract : Reducing infant mortality began from antenatal care and continues with good intranatal treatment. Enforcing an accurate diagnosis of premature rupture of membranes can prevent further complications for mother and fetus. Base values in amniotic fluid are the key in establishing a diagnosis of premature rupture of membranes, litmus test is a commonly used measurement of alkaline levels in the measurement with this method litmus discoloration is not clear on the amniotic fluid number 3 and number 5 respondents. Comparative measurements made on 5 respondents using the nutron $\mathrm{pH}$ meter brand $\mathrm{PH}-009-\mathrm{A}$ by measuring the same amniotic fluid of respondents, obtained showing results - the following is the $\mathrm{pH}$ value of 8.1 for the first respondent, $\mathrm{pH}$ of 8.3 for number two respondents, $\mathrm{pH} 7.4$ for number three respondents, $\mathrm{pH} 8.7$ for respondent number four, and $\mathrm{pH} 8.0$ for respondent number five. litmus test gave vaguely color changes at $\mathrm{pH} 7.4$ and $\mathrm{pH}$ 8.0. Theoretical conclusions through the literature review explain that accurate $\mathrm{pH}$ measurements can provide data interpretation as
\end{abstract}


follows: Pregnancy age, surfactant levels that indicate fetal maturity, gestational age, intrauterine complications such as fetal distress and intrauterine infection.

\section{Keyword : pH meassurance, amniotic fluid, pH meter, litmus test}

\section{PENDAHULUAN}

Air Ketuban adalah bagian paling penting dalam masa kehamilan, cairan ini melindungi bayi dari trauma, memberikan ruang untuk pertumbuhan janin dan mencegah tali pusat mengalami kompresi dari luar,(Pilliod et al., 2015) selain itu cairan ketuban adalah mediator utama untuk mengetahui segala informasi tentang janin yang ada didalam uterus, cairan ketuban menyediakan daya pantul akustik yang memfasilitasi pencitraan ultasonografi dan pemanfaatan dopler untuk memantulkan detak jantung janin.(Murphy \& Koos, 2018). Cairan ketuban juga memiliki sifat bakteriostatik yang berfungsi melawan infeksi bakteri dari luar.(Luo et al., 2018)

Adanya meconium pada kehamilan trimester 3 adalah informasi penting yang diperoleh dari cairan ketuban, bercak mekonium pada ketuban tidak hanya memberi informasi terjadi kondisi fetal distress (Pop \& Kuppens, 2014) tetapi juga dapat memberikan informasi usia kehamilan atau maturitas bayi. Berdasarkan riset yang dilakukan oleh Carr dkk pada 3.041 wanita melahirkan di Ausralia menyatakan bahwa usia kehamilan memiliki hubungan kuat dengan cairan amnion bernoda meconium pada kehamilan lebih atau sama dengan 42 minggu. (Carr, Copnell, \& McIntyre, 2018)

Kadar PH pada cairan ketuban adalah satusatunya informasi yang digunakan di Fasilitas Kesehatan primer yang ada di Indonesia, cairan ketuban memiliki kadar alkaline atau bersifat basa dengan nilai $\mathrm{pH} \quad 6,9$ - 8.2 (Kanmaz, Yağmurlu, Aktuğ, \& Gökçora, 2001). Bahan yang digunakan sebagai indikator $\mathrm{pH}$ adalah kertas litmus atau kertas lakmus, alat ukur ini digunakan karena sifat membrane permiabitas yang ada pada kertas lakmus memudahkan sisa air ketuban yang ada disarung tangan terserap dan memberikan perubahan warna, informasi yang didapatkan dengan metode ini adalah kuantitatif yaitu ketuban pecah atau belum, dikatakan ketuban possitive apabila kertas lakmus berwarna merah berubah warna menjadi biru (basa) atau kertas lakmus biru berubah warna menjadi pink. (Tahir, 2008)Kendala pada metode ini adalah apabila cairan ketuban sudah kering atau bercampur dengan cairan vagina dan lendir darah akan memberikan hasil positive palsu.

Ketuban pecah dini terjadi pada $10 \%$ kehamilan, 7\% pada kehamilan aterm dan 3\% pada kehamilan premature. Membuat diagnosis dini serta akurat untuk kejadian Ketuban Pecah Dini sangat penting, agar dapat melakukan intervensi yang spesifik sesuai dengan usia kehamilan dan mengoptimalkan hasil perinatal. (Singh \& Bhat, 2014) Insiden Ketuban Pecah Dini di Indonesia sebanyak 12\% pada tahun 2010. (Irsam, Dewi, \& Wulandari, 2017). Di RSUD Tugurejo tahun 2013 kejadian ketuban pecah dini sebesar $24 \%$ dari total persalinan. (UPT Rekam Medis RSUD Tugurejo, 2013) mengetahui kadar $\mathrm{pH}$ secara pasti dalam cairan ketuban dapat memberikan informasi yang lebih banyak terkait kondisi janin didalam uterus, informasi ini dibutuhkan karena beberapa alasan antara lain diagnosa yang tepat akan mendukungprofilaksi yang adekuat sehingga dapat mencegah infeksi intrapartum maupun postpartum.(Palacio et al., 2008)

Penilaian warna secara
dengan pederhana
dimanfaatkan untuk membuat
brediktor
tinngkat kesejahteraan janin dalam
rahim. Warna kuning untuk cairan ketuban
yang sedikit tercemar meconium, warna hijau
untuk cairan ketuban yang keruh kehijaun dan
warna coklat kental pekat seperti sub kacang
menunjukan kontaminasi mekonium yang
berlebihan. Pada pengukuran pH tali pusat


janin melalui analisa gas darah, segera setelah lahir didapatkan hasil semakin gelap warna mekonium dalam cairan ketuban semakin kuat sifat alkaline cairan ketuban yang dimiliki (Rodríguez Fernández, López Ramón y Cajal, Marín Ortiz, \& Couceiro Naveira, 2018)

Alat ukur $\mathrm{pH}$ tidak hanya menginterprestasi cairan ketuban positive ataupun negative tetapi juga dapat memberikan informasi tambahan tentang usia kehamilan dan tingkat sejahteraan janin dalam rahim, walau dengan volume yang sangat minim sekalipun.

\section{METODE PENELITIAN}

Penelitian ini adalah penelitian retroflektif, yaitu dengan mengambil sisa cairan ketuban ibu pada saat bersalin kemudian menelusuri mundur rekam medis ibu untuk melihat usia kehamilan, riwayat kehamilan, dan faktor penyulit yang lain. Populasi pada penelitian ini adalah semua ibu inpartu yang melahirkan di ruang bersalin RSUD Tugurejo, Kota Semarang tanggal 23 Juli 2018 s/d 27 Juli 2018 pada shift pagi, sampel diambil secara incidental dengan teknik total sampling. Alat ukur yang digunakan pada penelitian ini adalah $\mathrm{PH}$ meter dengan merk Nutron.tech seri PH-009A, serta kertas lakmus warna merah sebagai kontrol.

\section{HASIL PENELITIAN}

Jumlah Ibu inpartu pada periode 23 Juli 2108 - 27 Juli 2018 adalah 7 pasien, 2 pasien drop out karena ketuban kering bahkan setelah bayi lahir jumlahnya tidak cukup untuk dilakukan pengukuran, sehingga total Responden adalah 5 orang. Setelah dilakukan pengukuran $\mathrm{pH}$ dan meneluri rekam medis kebelakang, didapat hasil bahwa pada kehamilan 40 minggu - 42 minggu sifat air ketuban menjadi lebih basa dibandingkan dengan pada ibu inpartu dengan usia kehamilan kurang dari 40 minggu, hal yang sama juga terjadi pada responden dengan penyulit ketuban pecah dini sifat air ketubanya menjadi lebih basa. Karateristik responden dikelompokkan dalam table 1

Tabel 1. hasil pengukuran cairan ketuban dengan pH meter digital

\begin{tabular}{cccccc}
\hline No & pH & $\begin{array}{c}\text { Warna } \\
\text { lakmus }\end{array}$ & $\begin{array}{c}\text { Warna } \\
\text { ketuban }\end{array}$ & $\begin{array}{c}\text { Usia } \\
\text { kehamilan }\end{array}$ & $\begin{array}{c}\text { Peny- } \\
\text { ulit }\end{array}$ \\
\hline 1 & 8.1 & Pink & Jernih & 39w 4h & - \\
\hline 2 & 8,3 & Pink & Jernih & 38w 3h & KPD \\
\hline 3 & 7,4 & $\begin{array}{c}\text { Biru } \\
\text { pudar }\end{array}$ & Jernih & 38w 2h & - \\
\hline 4 & 8.7 & Pink & Kental & 41w 5h & - \\
\hline 5 & 8.0 & $\begin{array}{c}\text { Pink } \\
\text { samar }\end{array}$ & Keruh & $39 w 1 h$ & - \\
\hline
\end{tabular}

Pada responden ke-3 warna kertas lakmus biru tidak berubah warna secara significan pada cairan ketuban dengan nilai $\mathrm{pH} 7.4$ sehingga menimbulkan kesan negative palsu. Menurut teori asam basa. Suatu unsur dikatakan bersifat basa atau alkali jika memiliki skala $\mathrm{pH} 7-14$, sementara dikatakan sebagai asam jika memiliki kadar $\mathrm{pH}$ 0-7. Nilai PH netral adalah 7 dengan toleransi 0,5 diatas dan 0,5 dibawah score 7. Pada responden ke-3 ketuban tidak memberikan perubahan warna pada kertas lakmus karena cairan dalam suasana konsentrasi $\mathrm{pH}$ mendekati netral.(mettler, 2013)

Terjadinya hasil negative palsu pada pemeriksaan nitrazin test dipengaruhi banyak faktor, bisa dari kwalitas ketas yang memang sudah tidak baik karena teroksidasi sehingga indikator warna tidak bereaksi sesuai nilai $\mathrm{pH}$ yang sesunggungnya. Faktor anatomi dan fisiologi organ reproduksi juga tidak dapat diabaikan.Cairan vagina mengandung banyak ion hidronium $(\mathrm{H} 3 \mathrm{O}+)$ dan kelebihan ion hidronium ini dalam larutan membuat sifatnya menjadi asam, sementara cairan ketuban bersifat basa/alkaline dengan kelebihan ion hidrosil (OH-). Pada reaksi kimia saat cairan vagina yang bersifat asam bercampur dengan cairan ketuban yang bersifat basa akan menghasilkan larutan yang memiliki sifat netral, dijelaskan dalam persamaan kimia dengan $(\mathrm{H} 3 \mathrm{O}+)+(\mathrm{OH}-) \leftrightarrow$ 
2H20. Terutama jika pengukuran dilakukan pada sarung tangan latek yang sudah bersinggungan dengan cairan vagina terlebih dahulu sebelum sampai pada kulit ketuban. (mettler, 2013)

\section{PEMBAHASAN}

Pada Responden dengan usia kehamilan 41 minggu 3 hari, memiliki kadar $\mathrm{pH}$ dalam cairan ketuban 8.7, nilai ini adalah angka paling tinggi dibandingkan 4 responden yang lain. Penulis belum mampu mengeneralisasikan apakah ibu hamil dengan serotinus memiliki kondisi ketuban yang lebih basa dibandingkan dengan cairan ketuban pada ibu hamil dibawah 40 minggu. Pada kehamilan lewat waktu, konsentasi cairan ketuban semakin pekat, ini terjadi karena berkurangnya produksi urine janin. Konsentrasi pemekatan tsb berpengaruh terhadap kadar $\mathrm{pH}$ dalam cairan ketuban, selain itu semakin matur paru-paru janin semakin banyak surfactant yang dikeluarkan dan terlarut dalam cairan ketuban disertai dengan klorida sifat senyawa tersebut adalah alkaline sehingga kadar $\mathrm{pH}$ meningkat. (Beloosesky \& Ross, 2018)

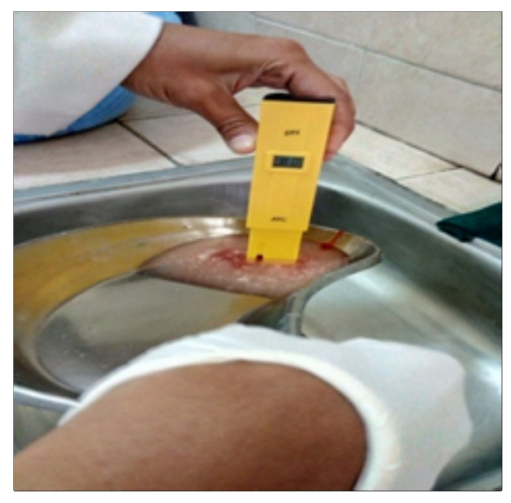

Gambar. 1 pengukuran $\mathrm{pH}$ ketuban dengan $\mathrm{pH}$ meter nutron seri $\mathrm{PH}-009-\mathrm{A}$

Cairan ketuban yang pecah merupakan sinyal penting dalam membuat prognosa selama persalinan. Pada Responden ke-2 memiliki penyulit dalam persalinan yaitu Ketuban Pecah Dini, 32 jam . Pada penelitian yang dilakukan oleh (Martinez-Varea et al.,
2017) air ketuban yang terinsfeksi bakteri streptococcus agalactiae, ureaplasma urealyticum, gardnerella vaginalis dan echerichhia coli dalam cairan ketuban banyak ditemukan neutrofil yang bersifat fagositosis (Romero et al., 2007), (Romero et al., 2015). Neutrofil cairan amnion adalah bagian pertahanan imun bawaan, yaitu mekanisme yang terjadi di ruang ketuban untuk melawan infeksi intraamniotik.(Underwood, Gilbert, \& Sherman, 2005) Neutrofil ini berasal dari DNA ibu maupun DNA janin dengan komposisi yang berbeda pada setiap kasus (Gomez-Lopez et al., 2017). Tingginya kadar neutrofil ada cairan amnion membuat sifatnya lebih basa, seperti dijelaskan dalam penelitian alawiyah 2006 "neutrofil merupakan komponen sel yang bersifat basa". (Indriani, 2017)

\section{KESIMPULAN}

Perubahan warna kertas lakmus pada Cairan amnion yang diamati pada 5 responden tidak menunjukan hasil yang konsisten, pada responden nomer 3 dan responden nomer 5 kertas lakmus tidak menunjukan perubahan warna yang jelas. Penulis tidak berani melakukan generelasasi hasil karena jumlah responde yang terlalu sedikit dan kondisi kertas lakmus sebelum pengamatan tidak dilakukan uji sensitifitas dan reliabilitas terhadap perubahan $\mathrm{pH}$ pada cairan asam dan basa selain amnion.

Kesimpulan teoritik yang diperoleh dari hasil pengamatan dan systematic review cairan ketuban memberi banyak informasi yang diperoleh melalui pengukuran $\mathrm{pH}$ antara lain : warna cairan amnion menunjukan komplikasi dan prognosa terjadinya fetal distress. Dalam cairan ketuban terdapat sel neutrofil yang menunjukan potensi infeksi dapat diukur dengan sederhana menggunakan kadar $\mathrm{pH}$ karena sel-sel neutrofil akan membuat suasana air ketuban lebih basa, usia kehamilan juga mampu diprediksi dari cairan amnion yang diukur nilai $\mathrm{pH}$ dengan cermat semakin basa cairan ketuban usia kehamilanya semakin tua karena produk dari 
urine janin dan surfactant paru yang telah matang dan terlepas ke cairan ketuban.

Diagnosa Ketuban pecah dini yang tepat adalah kunci untuk melakukan manajemen yang efektif pencegahan komplikasi guna menurunkan angka kematian bayi. Cairan ketuban adalah pesan pertama yang didapat untuk melakukan interprestasi kesejahteraan fetomaternal.

\section{SARAN}

Pengukuran secara kuantitas menggunakan kertas lakmus perlu dilakukan pengujian ulang sesitifitas dan reliabilitas pada cairan ketuban dengan jumlah sampel yang besar, selain itu perlu dikembangkan melalui penelitian lebih lanjut pengembangan alat pengukuran $\mathrm{pH}$ yang mampu menjelaskan secara akurat nilai kadar $\mathrm{pH}$ yang ada pada cairan amnion sehingga didapat beberapa interprestasi data untuk mendukung diagnosa yang akurat sebagai salah satu upaya mencegah komplikasi fetomaternal seperti infeksi intrauterin, fetal distress, bahkan sepsis neonatorum dan sepsis maternal yang berawal dari manajemen pra persalinan yang tidak adekuat.

\section{DAFTAR PUSTAKA}

Beloosesky, R., \& Ross, M. G. (2018). Amniotic Fluid. In M. K. Skinner (Ed.), Encyclopedia of Reproduction (Second Edition) (pp. 380-386). Oxford: Academic Press.

Carr, B. L., Copnell, B., \& McIntyre, M. (2018). Differences in meconium stained amniotic fluid in an Australian population: A retrospective study. Women and Birth. doi: https://doi.org/10.1016/j.wombi.2018.06 .001

Gomez-Lopez, N., Romero, R., Xu, Y., Leng, Y., Garcia-Flores, V., Miller, D., . . . Alsamsam, A. (2017). Are amniotic fluid neutrophils in women with intraamniotic infection and/or inflammation of fetal or maternal origin? American journal of obstetrics and gynecology, 217(6), 693. e691-693. e616.

Indriani, M. (2017). PENGARUH KONSENTRASI pH BUFFER GIEMSA TERHADAP MORFOLOGI LEUKOSIT PADA PREPARAT SUMSUNG TULANG. Universitas Muhammadiyah Semarang.

Irsam, M., Dewi, A. K., \& Wulandari, E. (2017). Jumlah Paritas dan Anemia sebagai Faktor Prediktor Kejadian Ketuban Pecah Dini. Jurnal Kedokteran Muhammadiyah, 5(2).

Kanmaz, T., Yağmurlu, A., Aktuğ, T., \& Gökçora, H. (2001). The effect of amnio-allantoic fluid $\mathrm{pH}$ on the intestines: an experimental study in the chick embryo gastroschisis model. Journal Of Pediatric Surgery, 36(9), 1341-1345.

Luo, H., Xie, A., Hua, Y., Wang, J., Liu, Y., \& Zhu, X. (2018). Aquaporin 1 gene deletion affects the amniotic fluid volume and composition as well as the expression of other aquaporin water channels in placenta and fetal membranes. Clinica Chimica Acta, 482, 161-165.

doi: https://doi.org/10.1016/j.cca.2018.04.00 1

Martinez-Varea, A., Romero, R., Xu, Y., Miller, D., Ahmed, A. I., Chaemsaithong, P., . . . Lannaman, K. (2017). Clinical chorioamnionitis at term VII: the amniotic fluid cellular immune response. Journal of perinatal medicine, 45(5), 523-538.

mettler, T. (2013). A Guide to $p H$ Measurement, Theory and Practice of pH Applications. Switzwrland: MettlerToledo GmBH.

Murphy, A., \& Koos, B. (2018). The Amnion and Amniotic Fluid. In M. K. Skinner (Ed.), Encyclopedia of Reproduction (Second Edition) (pp. 562-568). Oxford: Academic Press.

Palacio, M., Cobo, T., Figueras, F., Gómez, O., Coll, O., Cararach, V., \& Gratacós, 
E. (2008). Previable rupture of membranes: effect of amniotic fluid on pregnancy outcome. European Journal of Obstetrics \& Gynecology and Reproductive Biology, 138(2), 158-163.

Pilliod, R. A., Page, J. M., Burwick, R. M., Kaimal, A. J., Cheng, Y. W., \& Caughey, A. B. (2015). The risk of fetal death in nonanomalous pregnancies affected by polyhydramnios. American journal of obstetrics and gynecology, 213(3), 410. e411-410. e416.

Pop, V. J., \& Kuppens, S. M. (2014). Management strategy in case of meconium stained amniotic fluid. Early Human Development, 90(7), 341-342. doi:

https://doi.org/10.1016/j.earlhumdev.20 14.04.004

Rodríguez Fernández, V., López Ramón y Cajal, C. N., Marín Ortiz, E., \& Couceiro Naveira, E. (2018). Intrapartum and perinatal results associated with different degrees of staining of meconium stained amniotic fluid. European Journal of Obstetrics \& Gynecology and Reproductive Biology, 228, 65-70. doi: https://doi.org/10.1016/j.ejogrb.2018.03. 035

Romero, R., Espinoza, J., Gonçalves, L. F., Kusanovic, J. P., Friel, L., \& Hassan, S. (2007). The role of inflammation and infection in preterm birth. Paper presented at the Seminars in reproductive medicine.

Romero, R., Miranda, J., Chaemsaithong, P., Chaiworapongsa, T., Kusanovic, J. P., Dong, Z., . . . Yoon, B. H. (2015). Sterile and microbial-associated intraamniotic inflammation in preterm prelabor rupture of membranes. The Journal of Maternal-Fetal \& Neonatal Medicine, 28(12), 1394-1409.

Singh, C. R., \& Bhat, R. G. (2014). Alphafoetoprotein in the diagnosis of prelabour rupture of membranes. Journal Of Clinical And Diagnostic Research: JCDR, 8(11), OC01-OC02. doi: $10.7860 /$ jedr/2014/8259.5093

Tahir, I. (2008). Arti Penting Kalibrasi pada Proses Pengukuran Analitik: Aplikasi pada Penggunaan pHmeter dan Spektrofotometer UV-VIS. Yogyakarta: Universitas Gajah Mada.

Underwood, M. A., Gilbert, W. M., \& Sherman, M. P. (2005). Amniotic fluid: not just fetal urine anymore. Journal of perinatology, 25(5), 341. 